\title{
Conjoined Sternophagus Twin Monster: A Cause of Dystocia in Murrah Graded Buffalo
}

\author{
Pravesh Kumar, Sadiya Basir, Madhumeet Singh and Akshay Sharma* \\ Department of Veterinary Gynaecology and Obstetrics, DGCN College of Veterinary and Animal Sciences, India
}

Submission: September 27, 2018; Published: October 16, 2018

*Corresponding author: Akshay Sharma, Department of Veterinary Gynaecology and Obstetrics, DGCN College of Veterinary and Animal Sciences, CSK Himachal Pradesh Krishi Vishwavidyalaya, Palampur (HP), India- 176062, Tel: 8894944243; Email id: akshays482@gmail.com

\begin{abstract}
A 6 years old murrah graded buffalo in second lactation with the history of 305 days of gestation was presented in the jurisdiction of veterinary hospital Hamirpur, Himachal Pradesh. The animal had started showing signs of labor 3 hours prior to its presentation. Per vaginal examination revealed fetus in anterior presentation, dorso-sacral position with two heads and four forelimbs, which confirmed it to be a case of fetal dystocia due to either twin pregnancy or fetal abnormalities. Per vaginal manipulation of fetus was attempted by mutations but proportionately large size of abnormal fetus impeded the process. Adopting caesarian section as means of fetal delivery was opted and a sternophagus twin monster was delivered.
\end{abstract}

Keywords: Sternophagus; Murrah graded buffalo; Dystocia; Caesarian section

\section{Introduction}

Dystocia is a most commonly observed in bovines and the condition is developed when the birth process is hampered by some physical obstacle or functional defects [1]. Any fetal defect such as fetal monster may result in distortion of body configuration and can become a reason of dystocia in bovines $[2,3]$. An incidence of fetal monstrosities was recorded up to $7.9 \%$ [4] to $12.8 \%$ [5] in river buffaloes. Most of the monstrosities observed in water buffalo and little data is available for swamp buffaloes. Monstrosities causing dystocia are most likely to be relieved by caesarian section $[3,6,7]$. It is strenuous for the fetal monster to pass through the birth canal either owing to the altered shape they possess or their relative size. Most usual encountered fetal monsters are Schistosoma reflexus, Perosomus elumbis, conjoined twins and cyclopia [8].

The conjoined twins are two fetuses secured together and arise typically from a single ovum and are monozygotic occurring because of incomplete division of a fertilized ovum and display great discrepancy from incomplete duplication to almost complete separation of two individuals, joined in just a few places [8]. Conjoined twins are non-inherited teratogenic defects [2]. It is believed that some factors are responsible for the failure of twins to separate after the $13^{\text {th }}$ day after fertilization those results in conjoined twins [9]. Conjoined twins monozygotic in origin may be fused medially at different parts of body but the cranial fusion is noted to be commonest of all [8].

\section{Case History}

A Murrah graded buffalo aged about 6 years in second parity was presented with the history of 305 days of pregnancy was presented in the jurisdiction of veterinary hospital Hamirpur. Animal was straining for last 3 hours with two visible limbs in the vagina. When the animal was presented, the water bags had already ruptured as the case was manipulation by local para-veterinary staff. The animal was alert and was in good body condition with rectal temperature of $100.9^{\circ} \mathrm{F}$. Vaginal mucus membrane was congested and edematous with negligible lubrication. Per vaginal examination revealed complete dilation of cervix with more than two fore limbs and two heads in the birth canal suggestive of the conjoined twin fetus. Both the fetuses were in anterior longitudinal presentation with dorso-sacral position. Per vaginal delivery was attempted to relieve dystocia by mutation, forced extraction after achieving adequate lubrication of birth canal, yet unsuccessful to deliver the fetus. Disproportionate size of the mother and the monster fetus justified caesarian to alleviate the condition.

\section{Result and Discussion}

Cesarean was conducted under local anesthesia which was achieved by using $90 \mathrm{ml}, 2 \%$ lignocaine hydrochloride in linear infiltration. Caesarian section was performed in the left lateral recumbancy. An oblique vento-lateral incision was given, and a dead male conjoined twin monster was removed. The surgical wound was sutured in routine fashion by using chromic catgut no. 2. The uterus was sutured by Cushing suturing pattern. The first and second muscle layers were sutured by lock stitch and simple continuous suture pattern, respectively. Skin was sutured with silk by using simple interrupted suture pattern. The buffalo was treated with inj. Strepto-penicillin 5.0gm and inj. Meloxicam $15 \mathrm{ml}$ through intramuscular route for 5 days. The supportive therapy was done with inj. Normal saline and Ringer's lactate 4 liter 
each through intravenous route only once. Antiseptic dressing of surgical wound was done with povidone iodine and removal of suture was done after 12 days of the surgery.

The fetus was conjoined at sternum region of the thorax and both the heads were opposite to each other. Grossly the fetus possessed two normal heads, with separate nostrils, eyes and ears. According to Camon [10] dicephalic fetus could manifest any of the following feature; Atlodymus (two complete and separate skulls and single neck), Iniodymus (two skulls with fusion at the occipital region) and derodymus (two complete and separate skulls with two separate necks). In accordance with this nomenclature, the present fetus was derodymus dicephalic, distomus, tetraopthalmus, tetraotus, tetrabrachius, tetrapus, and dicaudatus conjoined sternopagus twin monster male buffalo calf (Figure 1). Similar findings in a buffalo conjoined monster were reported by Shukla [2].

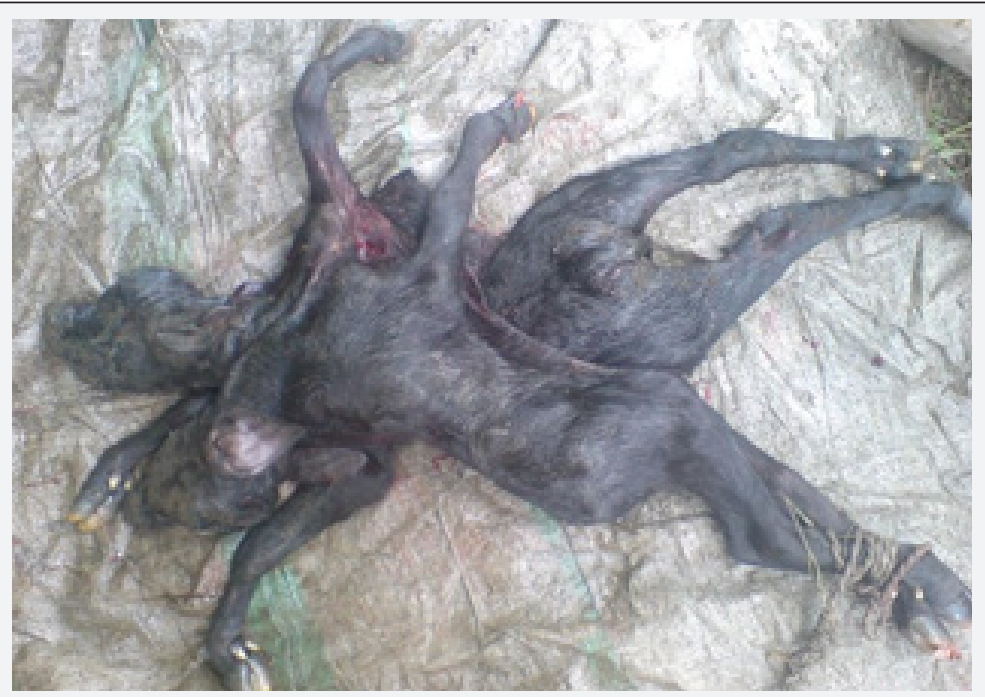

Figure 1: Dicephalus derodymus sternopagus tetrabrachius tetrapus dicaudatus monster.

\section{Conclusion}

A rare case of conjoint twin monster in buffalo manifesting duplication of external body parts was delivered successfully by cesarean section.

\section{References}

1. Srinivas M, Sreenu M, Lakshmi RN (2007) Studies on dystocia in graded Murrah buffaloes: a retrospective study in a cow. Buffalo Bulletin 26: 40-45.

2. Shukla SP, Garg UK, Pandey A, Dwivedi DP, Nema SP (2007) Conjoined twin monster in a buffalo. Indian Veterinary Journal 84: 630-631.

3. Kumar P, Sharma A, Singh M, Sood P, Barman P (2014) Dystocia due to dicephalus monster fetus in a buffalo. Buffalo Bulletin 33(1): 13-15.

4. Phogat JB, Bugalia NS, Gupta SL (1992) Incidence and treatment of various forms of dystocia in buffaloes. Indian Journal of Animal reproduction 13: 69-70.
5. Singla VK, Sharma RD (1992) Analysis of 188 cases of dystocia in buffaloes. Indian veterinary journal 69: 563-564.

6. Sharma A (2006) Caesarean section in animals under field conditions: A retrospective study of 50 cases. Indian Veterinary Journal 83(5): 54445.

7. Sharma A, Sharma S, Vasishta NK (2010) A diprosopus buffalo neonate: A case report. Buffalo Bulletin 29(1): 62-64.

8. Robert SJ (2004) Veterinary obstetrics and genital diseases. Indian reprints 2004, CBS Publishers and Distributors, Delhi-110032.

9. Vegad JL (2007) Textbook of Veterinary General Pathology, (2 $\left.2^{\text {nd }} e d n\right)$, International Book Distribution Company, Lucknow, UP, India, pp. 544.

10. Camon J, Sabate D, Verdu J, Rutllant J, Lopez-Plana C (1992) Morphology of a dicephalic cat. Anatomy and Embryology 185(1): 45-55. 
This work is licensed under Creative Commons Attribution 4.0 License DOI: 10.19080/JDVS.2018.08.555727

\section{Your next submission with Juniper Publishers} will reach you the below assets

- Quality Editorial service

- Swift Peer Review

- Reprints availability

- E-prints Service

- Manuscript Podcast for convenient understanding

- Global attainment for your research

- Manuscript accessibility in different formats ( Pdf, E-pub, Full Text, Audio)

- Unceasing customer service

Track the below URL for one-step submission https://juniperpublishers.com/online-submission.php 